\title{
PELATIHAN KETERAMPILAN MENULIS TEGAK BERSAMBUNG PADA GURU KELAS III SD YAPIS TEMINABUAN KABUPTEN SORONG SELATAN
}

\author{
Irwan Soulisa* \\ Fakultas Keguruan dan Ilmu Pendidikan Universitas Victory Sorong \\ *soulisairwan@gmail.com
}

\begin{abstract}
ABSTRAK
Berdasarkan observasi di kelas III SD Yapis Teminabuan ditemukan kesalahan-kesalahan dalam menulis huruf tegak bersambung. Sehingga, peneliti merumuskan masalah bagaimana menggunakkan metode Latihan Drill pada siswa untuk meningkatkan ketrampilan menulis huruf tegak bersambung. Tujuan untuk mengetahui penulisan huruf tegak bersambung menggunakan metode latihan Drill pada guru-guru terhadap siswa SD Yapis Teminabuan. Metode yang digunakan adalah metode latihan (Drill) yang menekankan pada kegiatan latihan yang dilakukan berulang-ulang secara terus menerus untuk menguasai kemampuan atau keterampilan tertentu kepada siswa SD. Teknik pengumpulan data dari siswa-siswi SD Yapis kelas III dan guru wali kelas. Hasil penelitian ini menunjukkan bahwa 100\% siswa dengan jumlah 35 siswa mengalami kesalahan dalam tulisan tegak bersambungnya. Kesalahan yang terjadi sebanyak 3107 kesalahan. Yakni (1) kesalahan berdasarkan aspek bentuk huruf (2) kesalahan berdasarkan aspek kerapian tulisan dan (3) kesalahan berdasarkan aspek kejelasan tulisan. Faktor penyebab kesalahan penulisan huruf tegak bersambung ini berasal dari siswa dan guru . Berdasarkan analisis data yang dilakukan, dapat disimpulkan bahwa $75 \%$ siswa sudah mampu menulis huruf tegak bersambung dengan cukup baik, hal ini dapat terlihat jumlah jenis kesalahan yang terjadi pada masing-masing hasil tulisan tegak bersambung siswa. Adapun saran yang dapat diberikan untuk guru kelas, agar memberikan pembelajaran tentang menulis huruf tegak bersambung dengan benar sesuai dengan kaidah Bahasa Indonesia yang ada.
\end{abstract}

Kata kunci: Ketrampilan Menulis, Huruf Tegak Bersambung

\section{ABSTRACT}

Based on observation in the class iii primary school yapis teminabuan found making mistakes in writing letters erect continued.So, researchers formulate the question of how menggunakkan method exercise drill to their students to increase skills letters erect continued.The purpose of know writing letters erect connecting uses the exercise drill in teachers think of elementary school students yapis teminabuan.Methods used is the method exercises (drill) that emphasizes the work of the exercise done repeated is constantly being to master ability or certain skills to elementary school students.Technique data collection of the primary school yapis class iii and teachers homeroom.This research result indicates that 100 percent of students to the number of 35 students experienced a mistake in writing erect bersambungnya.A fault that occurs as many as 3107 error.Namely ( 1 a based on the aspect of the form of the letter ( 2 a based on the aspect of neatness the literature and ( 3 ) Error based on the aspect of clarity writing. The causes of error accessing letters erect connecting it comes from students and teachers.Based on data analysis done, can be concluded that 75 percent of 
students are able to write letters erect connecting with good enough, this can be seen those kinds of a fault that occurs in each the results of writing erect connecting students.As for advice that can be assigned to class teachers, so as to give learning about writing letters erect connecting with right in accordance with rule existing indonesian language.

Keywords: Writing skills, the upright continued

\section{PENDAHULUAN}

Mempersiapkan sumber daya manusia yang berkualitas dan mampu berkompetisi dalam mengembangkan ilmu pengetahuan dan teknologi merupakan peranan dari pendidikan, sehingga pendidikan harus dilaksanakan dengan sebaik-baiknya untuk memperoleh hasil maksimal. Pendidikan hendaknya dikelola dengan baik, agar pendidikan yang tepat waktu dan tepat guna untuk mencapai tujuan pembelajaran dapat terlaksana. Sejalan dengan upaya pengembangan ilmu pengetahuan dan teknologi, sekolah merupakan lembaga formal penyelenggara pendidikan.

Namun, Sekolah Dasar (SD) sebagai salah satu lembaga formal dasar yang bernaung di bawah Departemen Pendidikan Nasional mengemban misi dasar dalam memberikan kontribusi untuk mencapai tujuan pendidikan nasional. Sekolah Dasar juga merupakan tempat yang penting bagi siswa untuk mengembangkan dirinya baik dalam hal kognitif, afektif, maupun psikomotorik. Siswa belajar mengkonstruksi pengetahuannya sendiri, bersosialisai, dan memperdalam setiap keterampilan dalam setiap mata pelajaran.

Selanjutnya, dalam menjunjung Tridarma Perguruan tinggi salah satu kegiatan yang dilakukan peneliti pada program studi Pendidikan Bahasa Indonesia Fakultas Keguruan dan Ilmu Pendidikan, melalui pelatihan kegiatan pembelajaran guru, terhadap siswa SD yang berada pada tahap operasi konkrit sudah semestinya dibekali dengan ilmu pengetahuan dasar dan keterampilan dasar yang dalam hal ini adalah mata pelajaran yang tercantum dalam kurikulum SD/MI untuk mengembangkan pengetahuan dan keterampilannya pada jenjang pendidikan selanjutnya. Salah satu mata pelajaran yang tercantum dalam kurikulum SD/MI adalah mata pelajaran Bahasa Indonesia. Mata pelajaran ini bertujuan untuk melatih siswa menggunakan bahasa Indonesia dengan baik dan benar yang merupakan bahasa nasional dan digunakan sebagai alat komunikasi dalam kehidupan sehari-hari.

Mengingat bahwa Bahasa Indonesia juga merupakan hal yang penting untuk kebutuhan siswa dalam penyampaian konsep, sehingga siswa mampu memahami pembelajaran dan menguasai keterampilan yang terdapat dalam Bahasa Indonesia yaitu 
keterampilan membaca, menulis, berbicara, dan mendengar. Keempat keterampilan ini akan dipelajari oleh siswa mulai dari kelas rendah hingga kelas atas, hal tersebut dimaksudkan agar siswa tidak hanya memahami materi pembelajaran yang berkaitan dengan empat keterampilan tersebut, akan tetapi juga mampu mengaplikasikannya dalam berkomunikasi pada kehidupan sehari-hari.

Berbagai permasalahan sering ditemukan dalam dunia pendidikan, begitu juga dengan mata pelajaran Bahasa Indonesia. Permasalahan yang muncul pada mata pelajaran Bahasa Indonesia dapat disebabkan oleh berbagai faktor seperti kurangnya keterampilan guru dalam menyampaikan materi, kurangnya antusias siswa dalam mengikuti pembelajaran, maupun kurangnya efektivitas waktu dalam kegiatan belajar. Melihat banyaknya permasalahan yang terjadi dalam dunia pendidikan terutama dalam mata pelajaran Bahasa Indonesia kelas atas, penulis melakukan observasi dan wawancara dengan guru kelas III di SD Yapis Teminabuan, Kab. Sorong Selatan.

Dengan demikian, Permasalah yang kami temukan salah satunya adalah permasalahan dalam keterampilan menulis, khususnya menulis menggunakan huruf tegak bersambung atau menulis halus. Keterampilan ini telah dipelajari siswa mulai dari kelas bawah, sehingga pada kelas atas siswa diharapakan mampu mengembangkan keterampilan menulis tegak bersambung yang telah dipelajarinya. Namun, pada kenyataannya banyak siswa yang masih kurang dalam keterampilan menulis tegak bersambung, seperti kurangnya pengetahuan siswa mengenai aturan-aturan dalam penulisan huruf tegak bersambung.

Oleh karena itu, tujuan dari pelatihan ini sebagai calon guru kita seharusnya mampu mengantisipasi permasalahan yang terjadi dalam pembelajaran Bahasa Indonesia khususnya pada keterampilan menulis tegak bersambung di kelas atas.

\section{MASALAH}

Hasil observasi pembelajaran Bahasa Indonesia kelas tiga di SD Yapis Teminabuan Kecamatan teminabuan kabupaten Sorong Selatan. menemukan permasalahan yang berhubungan dengan kemampuan siswa dalam keterampilan menulis, yaitu kurangnya kemampuan siswa dalam menulis tegak huruf bersambung dengan pemahaman huruf yang belum benar. Huruf-huruf tersebut misalnya bentuk huruf " $t$ "; huruf " $n$ " atau " $h$ " kapital; panjang huruf antara huruf "p", "g”, dan "y" adalah sama; kurang dalam memperhatikan tebal tipis huruf; tulisan kurang rapi dan indah; tulisan belum dapat terbaca dengan jelas. 
Penyebab timbulnya permasalahan bahasa Indonesia kelas tinggi di SD. Peneliti menemukan beberapa penyebab permasalahan dari hasil observasi dan wawancara dengan guru kelas, antara lain : 1) Siswa kurang terbiasa menggunakan tulisan tegak bersambung dalam kegiatan menulis sehari-hari. 2) Siswa terkadang masih menulis menggunakan huruf lepas dalam pembelajaran Bahasa Indonesia dan guru tidak terlalu mempermasalahkannya. 3) Ketika pembelajaran menulis tegak bersambung di kelas rendah, siswa kurang paham dengan aturan menulis tegak bersambung yang disebabkan dari kurangnya kemampuan guru dalam menanamkan konsep.

\section{METODE}

Metode latihan ( Drill) merupakan salah satu metode pembelajaran yang menekankan pada kegiatan latihan yang dilakukan berulang-ulang secara terus menerus untuk menguasai kemampuan atau keterampilan tertentu. Berdasarkan pendapat Roestiyah NK (2001: 125), metode drill adalah teknik yang dapat diartikan sebagai suatu metode mendidik dimana peserta didik melakukan kegiatan latihan agar peserta didik mempunyai keterampilan lebih tinggi dari yang dipelajari. Selain itu, suatu cara mengajar yang baik untuk menanamkan kebiasaan kepada siswa untuk memperoleh keterampilan, ketangkasan, kesempatan, dan kecepatan. Keterampilan tersebut dapat dikuasai dengan adanya kebiasaan-kebiasaan yang sudah terbangun pada siswa di SD Yapis Teminabuan.

Dalam penulisan tegak bersambung peneliti menggunakkan beberapa Fase penggunaan Pelatihan 1) Fase pemberian latihan merupakan Pertimbangan yang perlu diberikan kepada guru-guru terhadap siswa sebelum latihan diberikan antara lain: tujuan, jenis tugas, kemampuan siswa, dan waktu yang diberikan. Seluruh bertimbangan tersebut agar siswa tidak merasa terbebani melebihi kemampuannya. 2) Langkah pelaksanaan latihan Ketika latihan dilaksanakan perlu adanya dorongan atau motivasi dari guru agar siswa mampu melakukan sendiri, dan bukan malah menyuruh orang lain. Serta dianjurkan agar siswa mengingat apa yang telah dikerjakan. 3) Fase mempertanggungjawabkan latihan Fase ini berisi refleksi dari apa yang telah dipelajari, serta kendala apa saja yang ditemui siswa dalam proses pelaksanaan keterampilan menulis huruf tegak bersambung didapat solusi untuk mengatasi kendala tersebut agar kemampuan siswa menulis huruf tegak bersambung meningkat. 
Selanjutnya, Tahap pelatihan diawali dengan pengenalan hurup tegak bersambung kepada guru-guru sebelum pelatihan dimulai. selanjutnya materi pelatihan yang diberikan adalah menulis huruf tegak bersambung dan menulis huruf tegak bersambung dalam kalimat. Lokasi, waktu dan rincian kegiatan disajikan dalam sebagai berikut:

1. Lokasi

: SD Yapis Teminabuan

2. Waktu

: 10-11 November 2018

3. Rincian kegiatan

: tabel 1

Tabel 1. Rincian Kegiatan Pelatihan Pengabdian Masyarakat

\begin{tabular}{|l|c|l|}
\hline \multicolumn{1}{|c|}{ Hari/tanggal } & \multicolumn{1}{|c|}{ Jam } & \multicolumn{1}{c|}{ Kegiatan } \\
\hline Kamis & $09.00-9.30$ & Registrasi/ daftar hadir peserta \\
10 November 2018 & $9.30-10.00$ & Pembukaan dan perkenalan \\
& $10.00-11.00$ & Pengenalan huruf kepada peserta \\
& $11.00-12.00$ & Materi pelatihan (1) \\
& $12.00-13.00$ & Istirahat \\
\hline Jumat & $08.00-10.30$ & Pemateri pelatihan (2) \\
11 November 2018 & $10.30-12.00$ & Istirahat \\
\hline
\end{tabular}

\section{HASIL DAN PEMBAHASAN}

Permasalahan penulisan huruf tegak bersambung di SD Yapis Teminabuan masuk dalam katagori pembinaan. Hal ini menjadi perhatian khusus bagi guru-guru kelas III dan pemerintah daerah kabupaten Sorong Selatan. Upaya dengan pelatihan ini diharapkan menjadi solusi atas permasalahan yang terjadi. Sehingga, Penulisan Huruf Tegak Bersambung Sebagai Wujud Strategi Pembelajaran Guru. Menulis tegak bersambung merupakan salah satu keterampilan yang terdapat pada empat aspek pembelajaran Bahasa Indonesia dengan cara menggabungkan huruf demi huruf, sehingga membentuk suatu kata dan kalimat (Anggoro Theses; 2010). Pentingnya suatu kegiatan menulis dapat kita ukur dengan manfaat dari menulis itu sendiri. Dengan menulis, seseorang diharapkan mampu membuat suatu kata atau kalimat yang dapat dimengerti bukan hanya dirinya sendiri akan tetapi juga orang lain. 
Menuntaskan permasalahan tentang kurangnya keterampilan menulis tegak bersambung siswa SD dapat ditempuh beberapa cara, salah satunya adalah dengan meningkatkan keterampilan guru dalam melatih keterampilan menulis tegak bersambung siswa. Seorang guru harus mengetahui perkembangan Bahasa Indonesia dan tidak terbatas pada ruang kelas secara resmi (Adul:1981), oleh sebab itu untuk melatih siswa menulis tegak bersambung, guru memerlukan teknik-teknik khusus di dalam kelas untuk menyampaikan aturan-aturan penulisan huruf tegak bersambung. Seorang guru dituntut untuk membuat kegiatan pembelajaran yang menyenangkan, khususnya dalam melatih siswa menulis huruf tegak bersambung.

Menurut Prana, sebelum menulis seorang siswa harus melakukan kegiatan pramenulis seperti menggoreskan pensil atau menulis dengan jari diudara. Hal ini dimaksudkan agar siswa mencoba untuk melakukan gerakan-gerakan yang berhubungan dengan menulis secara tidak langsung. Begitu juga dengan menulis tegak bersambung, siswa perlu untuk melatih gerakan tangan mereka agar tangan dan jari menjadi mulai terbiasa dengan goresan-goresan huruf tegak bersambung. Menurut buku dari Amalia, 2010, ada beberapa langkah penulisan huruf tegak bersambung. Langkah-langkah ini perlu diperhatikan oleh seorang guru dalam melatih siswa-siswanya menulis huruf tegak bersambung, antara lain:

a. Pastikan siswa sudah dapat menguasai huruf cetak

b. Pengenalan huruf tegak bersambung dengan cara merangkai titik-titik yang nantinya apabila disambung akan membentuk abjad huruf tegak bersambung

c. Siswa juga bisa dibantu dengan menjiplak huruf tegak bersambung secara per huruf. Sediakan huruf tegak besambung secara lepas baik untuk huruf kecil atau huruf besar yang sudah tertulis pada kertas. Kemudian siswa diminta menjiplak tulisan kertas tersebut dengan menaruh kertas lain di atas kertas yang sudah ada tulisan huruf tadi.

d. Menggunakan buku halus serta menjelaskan ketentuan perbandingan tinggi huruf untuk belajar menulis huruf tegak bersambung. Langkah - langkah menulis dengan media buku halus:

1. Memulai menulis dengan huruf kecil

2. Mengenalkan bentuk baris-baris serta cara menulis dengan dimulai dari tepi bawah baris ke-3.

3. Sebelum menulis, siswa atau anak harus bisa membedakan huruf mana yang memiliki jambul atau ekor atau tidak memiliki keduanya atau memiliki kedua- 
duanya. Huruf berjambul ada 2 yaitu jambul penuh dan setengah. Jambul penuh seperti: b, h, k, 1 dan Jambul setengah seperti: d, t. Huruf berekor ada 2 yaitu ekor yang penuh dan setengah. Ekor penuh seperti: g, j, y dan Ekor setengah seperti: p, q. Huruf yang tidak memiliki jambul dan ekor seperti: a, c, e, i, m, n, o, r, s, u, v, w, x, z. Huruf yang memiliki ekor dan jambul sepert: $\mathrm{f}$

4. Ulangi terus-menerus sampai hafal.

5. Menulis huruf besar

a) Menulis huruf besar juga dimulai dari tepi bawah baris ke-3.

b) Huruf Besar ada dua tipe yaitu tingginyanya 3 baris dan 5 baris. Semua huruf besar mempunyai tinggi 3 baris (area menulis yaitu baris ke-1 sampai baris ke-3), kecuali pada huruf $\mathrm{G}$ dan $\mathrm{J}$ memiliki tinggi 5 baris (area menulisnya dari baris ke-1 sampai baris ke-5)

6. Jika sudah mahir menulis secara per huruf, bisa dilanjutkan dengan menulis kata, kemudian kalimat sederhana.

e. Ulangi kegiatan menulis atau biasakan siswa menulis menggunakan huruf tegak bersambung agar tangannya menjadi terampil dalam menulis huruf tegak bersambung.

f. Jika siswa sudah lancar menulis dengan buku halus, siswa dapat menulisnya di buku bergaris biasa.

Cara lain yang ditempuh oleh guru yaitu dengan menggunakan media-media yang dapat mendukung pemahaman siswa dalam menulis tegak bersambung. Media-media dibawah ini adalah contoh media yang dikembangkan oleh pembelajaran montessori, diantaranya:

a. Papan pasir

Papan ini terdiri dari nampan yang berisi pasir. Siswa dapat menuliskan contoh huruf pada papan ini dan dengan mudah siswa juga dapat menghapusnya. Papan pasir ini dapat membantu motorik halus siswa, sehingga siswa akan terbiasa dalam kegiatan menulis tegak bersambung.

b. Huruf pasir

Kartu ini terbuat dari kertas yang dilapisi oleh amplas kasar. Siswa meraba bagian kasar dari kartu huruf tersebut. Hal ini bertujuan untuk memaksimalkan fungsi indera peraba/sensorial. Guru juga bisa mengikuti suatu pelatihan untuk mengembangkan keterampilannya dalam menulis huruf tegak bersambung dan kemampuannya dalam melatih 
siswa untuk menulis huruf tegak bersambung. Hal ini dimaksudkan agar guru mendapatkan pengalaman-pengalaman baru mengenai kiat-kiat melatih keterampilan menulis tegak bersambung bagi siswa. Guru juga perlu mengajak siswa menulis dengan huruf tegak bersambung disetiap kesempatan tidak hanya dalam mata pelajaran Bahasa Indonesia.

Terakhir adalah memberikan motivasi siswa agar siswa terpacu keinginannya untuk berlatih menulis tegak bersambung secara terus menerus. Teori pengkondisian klasik menurut Pavlov mengupayakan latihan-latihan intensif melalui motivasi dan dorongan. Guru harus memunculkan minat menulis huruf tegak bersambung yang dimiliki oleh siswa. Guru mempunyai kewajiban untuk selalu memberikan pelatihan menulis tegak bersambung secara berkesinambungan untuk memberi motivasi pada siswa agar siswa merasa senang ketika menulis huruf tegak bersambung dan memiliki minat yang tinggi untuk berlatih menulis huruf tegak bersambung hingga pada akhirnya siswa menjadi terbiasa dan tangannya semakin terampil dalam menulis huruf tegak bersambung.

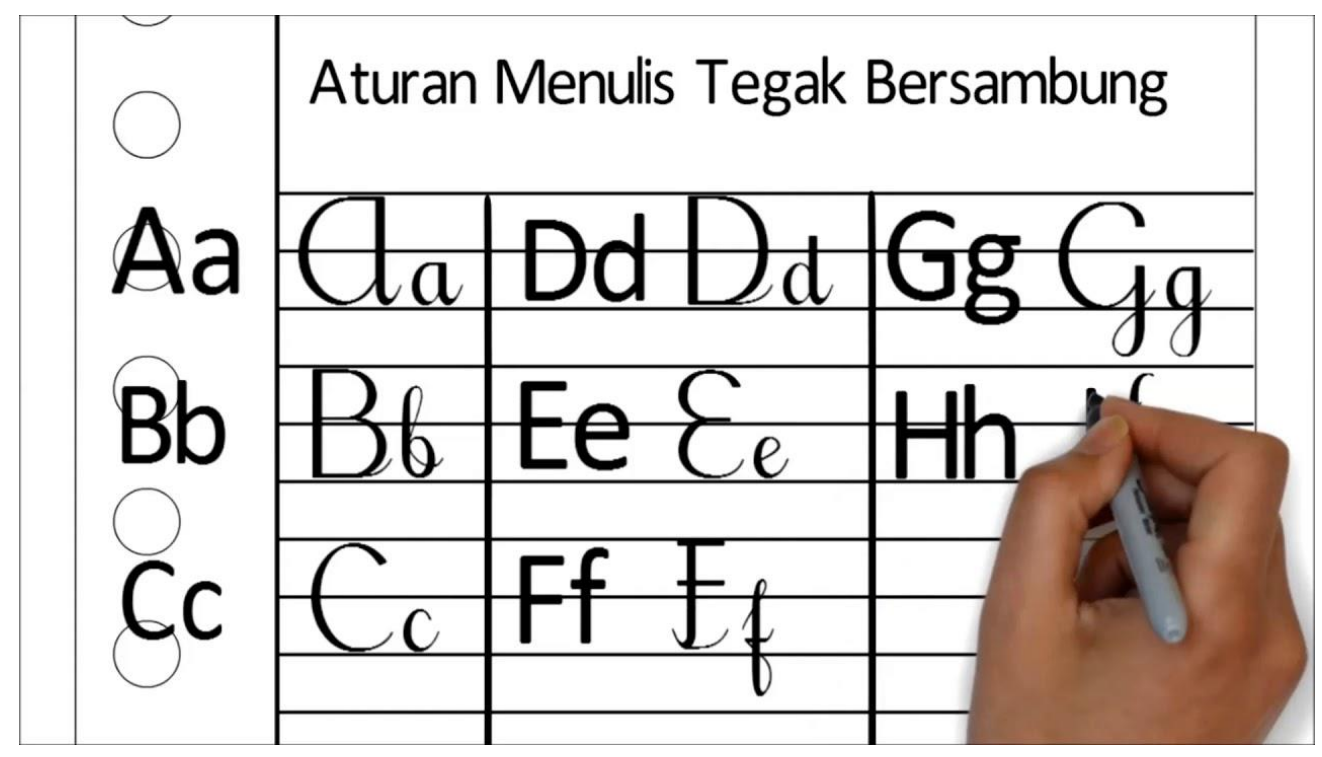

Gambar 1. Menulis Tegak Bersambung 

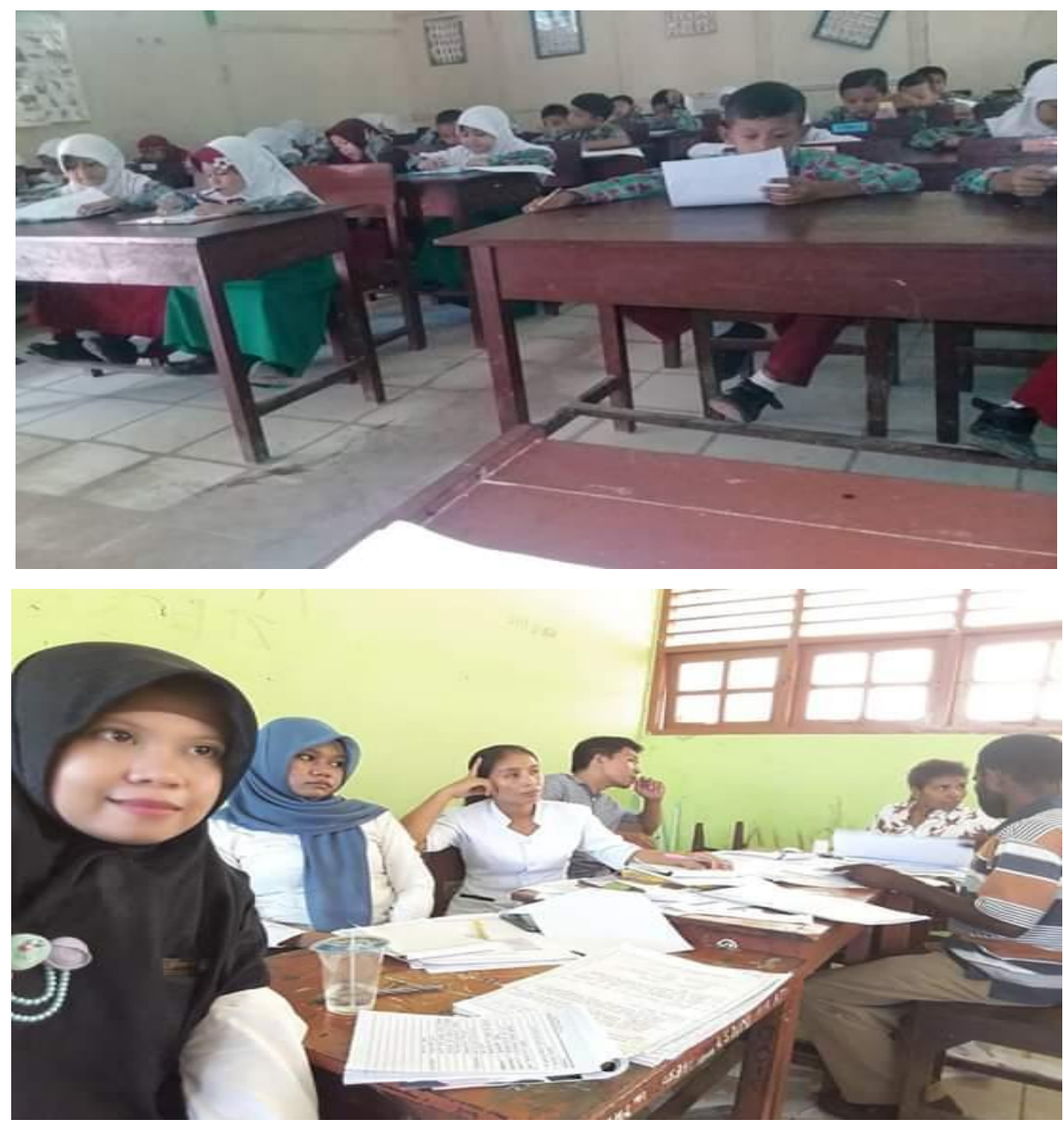

Gambar 2. Hasil Observasi Menulis Siswa dan Kegiatan Guru
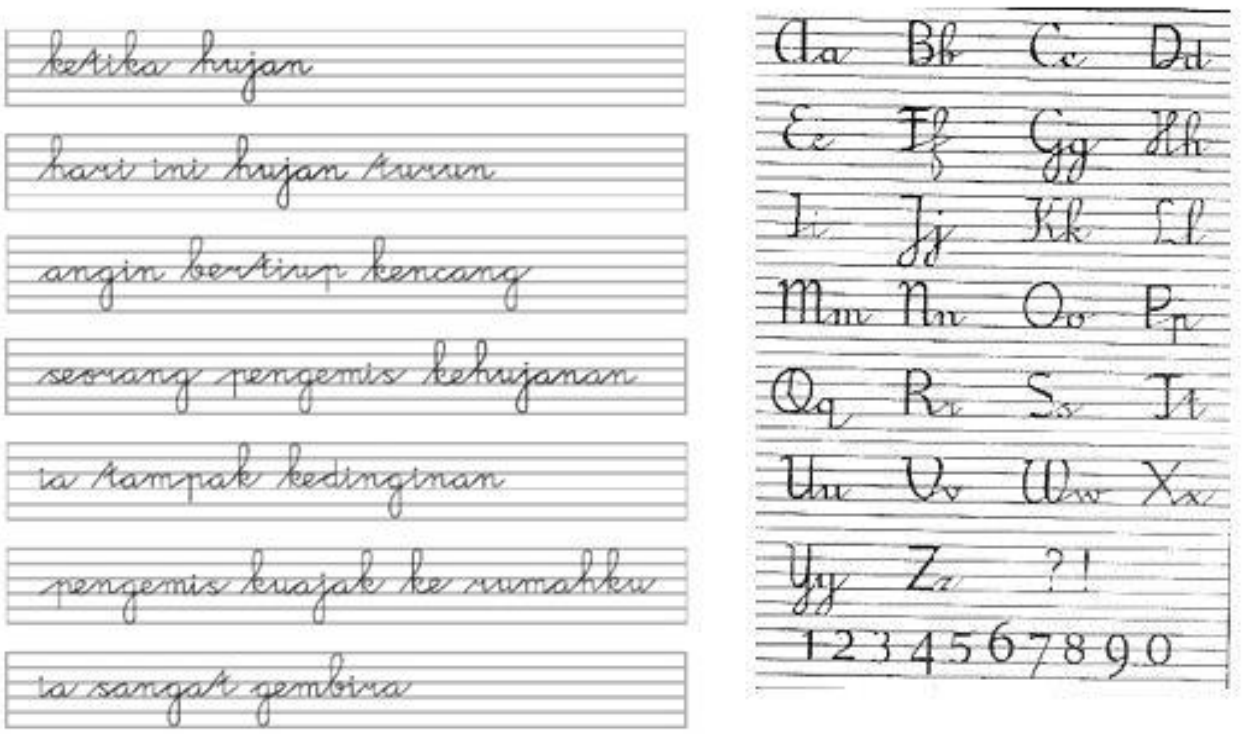

Gambar 3. Contoh Instrumen Latihan Menulis Kalimat 


\section{SIMPULAN}

Permasalahan yang muncul dari kegiatan menulis tegak bersambung dapat diatasi dengan pembelajaran yang efektif. Upaya-upaya guru untuk meningkatkan keterampilan menulis huruf tegak bersambung siswa, dapat dimulai dengan memberikan dasar-dasar menulis meliputi aturan penulisan dalam huruf tegak bersambung. Guru juga dapat menggunakan media pembelajaran yang mendukung dalam peningkatan keterampilan menulis huruf tegak bersambung yang dimiliki siswa. Hal yang utama yaitu guru terlebih dahulu meningkatkan keterampilannya dalam menulis huruf tegak bersambung. Selain itu guru juga perlu meningkatkan kemampuannya dalam melatih siswa menulis huruf tegak bersambung sesuai dengan langkah-langkah dan fase yang tepat dan tidak lupa untuk selalu mengajak siswa menulis dengan huruf tegak bersambung disetiap kesempatan tidak hanya dalam mata pelajaran Bahasa Indonesia.

\section{DAFTAR PUSTAKA}

Adu, Afandi. 1981. Bahasa Indonesia Baku dan Fungsi Guru dalam Pembelajaran Bahasa Indonesia. Surabaya: PT.Bima Ilmu.

Amalia, Citra. 2010. 6 Langkah Terampil Menulis Tegak Bersambung. Cikal Aksara.

Anggoro, Oktavianus Tri. 2010. Theses, Upaya Meningkatkan Keterampilan Menulis Tegak Bersambung Melalui Teori Pengondisian Klasik Siswa Kelas IIIB SD Bunda Mulia, Jakarta. Jakarta : Unika Atma Jaya.

Roestiyah NK. 2014. Strategi belajar mengajar. Jakarta: Reneka cipta

Tarigan, H.G. 1984. Menulis Sebagai Suatu Keterampilan Berbahasa. Bandung: Angkasa. 